Portland State University

PDXScholar

8-7-1992

\title{
Soviet Pentecostal Refugees' Health and Their Religious Beliefs: An Exploratory Study
}

Dianne Fae Venable

Portland State University

Follow this and additional works at: https://pdxscholar.library.pdx.edu/open_access_etds

Part of the Sociology Commons

Let us know how access to this document benefits you.

\section{Recommended Citation}

Venable, Dianne Fae, "Soviet Pentecostal Refugees' Health and Their Religious Beliefs: An Exploratory Study" (1992). Dissertations and Theses. Paper 4567.

https://doi.org/10.15760/etd.6451

This Thesis is brought to you for free and open access. It has been accepted for inclusion in Dissertations and Theses by an authorized administrator of PDXScholar. Please contact us if we can make this document more accessible: pdxscholar@pdx.edu. 
AN ABSTRACT OF THE THESIS OF DIANE FAE VENABLE for the Master of Science in Sociology presented August 7, 1992.

Title: Soviet Pentecostal Refugees' Health and Their Religious Beliefs: An Exploratory study.

APPROVED BY MEMBERS OF THE THESIS COMMITTEE:

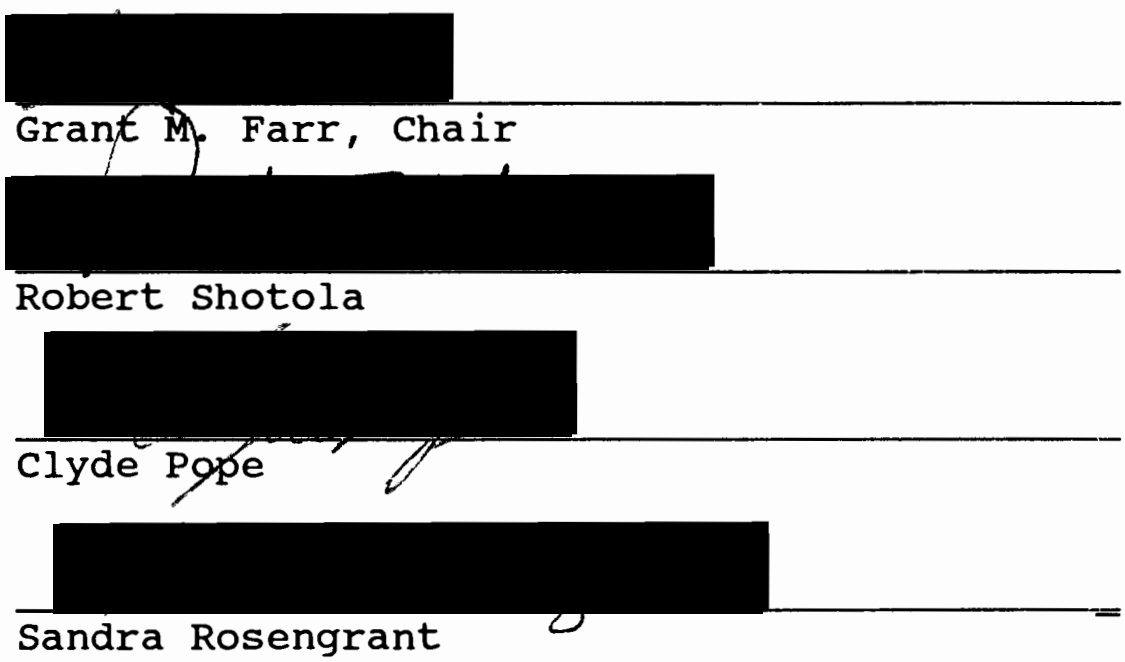

This thesis explored the health practices and religious beliefs of the recent Soviet Pentecostal refugee population in the Portland, oregon metro area. The methodology consisted of 25 in-depth interviews over a period of twelve months. Soviet Pentecostal refugees' health practices are influenced by their religious belief system which is Pentecostalism. The four primary factors that were found to have an affect on the refugees' health were lifestyle practices; coherence; or the meaning of suffering that 
religion provides; cohesiveness, or group belonging to the religious community, and world view provided by the underlying theology. The language barrier, distrust of outsiders, unfamiliarity with their belief system, and a limited understanding of their experiences of persecution may limit effective health care by professionals. 
SOVIET PENTECOSTAL REFUGEES' HEALTH PRACTICES AND RELIGIOUS BELIEFS: AN EXPLORATORY STUDY

by

DIANE FAE VENABLE

A thesis submitted in partial fulfillment of the requirements for the degree of

\author{
MASTER OF SCIENCE \\ in \\ SOCIOLOGY
}

Portland State University

1992 
TO THE OFFICE OF GRADUATE STUDIES:

The members of the Committee approve the thesis of Diane Fae Venable presented August 7, 1992.

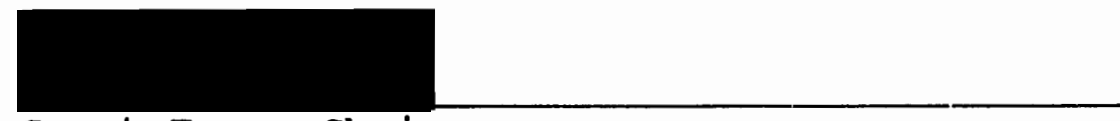

Grant Farr, Chair

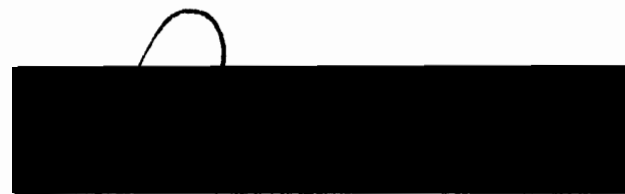

Robert Shotola
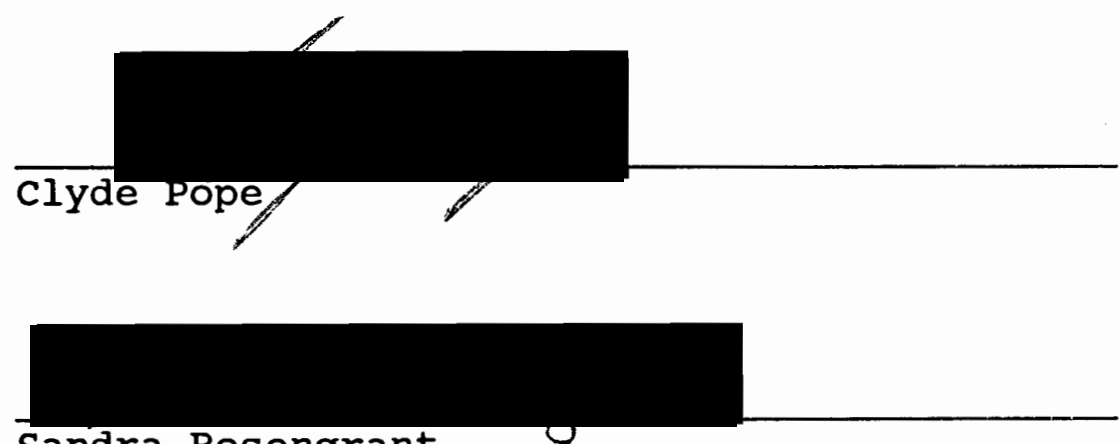

Sandra Rosengrant

APPROVED :

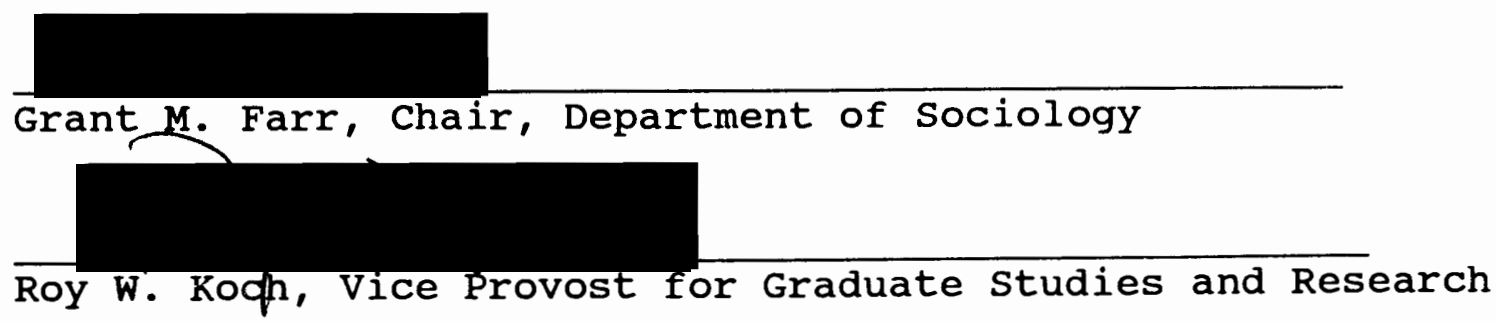




\section{ACKNOWLEDGEMENTS}

I would like to thank my husband and family for their continuous encouragement and support during this learning experience. I would also like to thank my thesis committee: Dr. Grant Farr whose early interest in my ideas and generous investment in time and energy was instrumental to the completion of this project; Dr. Robert Shotola for suggestions and clarification of various ideas; Dr. Clyde Pope for his willingness to serve on my committee. I would also like to thank Jean Siddall, department secretary for her able assistance and encouragement. I am also grateful to the twenty-five persons who invested their time to be interviewed so that the Russian Pentecostal refugees might be better understood. 
TABLE OF CONTENTS

PAGE

ACKNOWLEDGEMENTS . . . . . . . . . . . . . . .

CHAPTER

I INTRODUCTION . . . . . . . . . . . . 1

Statement of Purpose . . . . . . . 1

Review of Literature . . . . . . . 3

II BACKGROUND AND OVERVIEW . . . . . . . . 11

The Development of Pentecostalism . . 11

Development of Pentecostalism in the

Soviet Union . . . . . . . . . 18

Soviet Pentecostals in the U.S . . . . 22

III METHODOLOGY . . . . . . . . . . . 29

Data Collection . . . . . . . 29

Limitations and Advantages . . . . . 31

IV FINDINGS . . . . . . . . . . . . 34

Health Status When Entering America . 34

Health Practices and the

Supernatural . . . . . . . . 38

The Practices of Prayer and Divine

Healing on Health Care Utilization. . 40

Herbal Medicines, Religious Beliefs

and Health Care .. . . . . . . 44

Cohesiveness .. . . . . . . . . 46 
World view . . . . . . . . . 54

V SUMMARY . . . . . . . . . . . . . . . 55

REFERENCES • • • • • • • • • • • • • • • • • • • • • 57

APPENDIX • • • • • • • • • • • • • • • • • • • • • 65 
CHAPTER I

INTRODUCTION

STATEMENT OF PURPOSE

Although medicine and religion may appear to have little connection, religious beliefs and practices influence the attitudes and behaviors of many people throughout the world, including those attitudes and beliefs dealing with medicine and health.

For thousands of years medicine and religion have been tightly intertwined. Sickness and good health have been viewed by religions in supernatural terms (Byrne 1979). However, social service agencies and medical facilities generally approach health maintenance and curing disease from the physiological viewpoint. Studies show a relationship between health and religious beliefs, suggesting that more exploration of the role of spiritual beliefs for maintaining and curing health problems (Byrne 1979).

Therefore, the primary purpose of this thesis is to explore the health practices of the Soviet Pentecostal refugees in the Portland area and to relate these practices to their religious beliefs. These religious beliefs will be shown to influence their health status and their health practices. 
By examining the relationship between religion and health four primary factors, as proposed by Ellen Idler (1987) in the study of health and religion, will be utilized in this study. These factors link religion to health. They are: 1) lifestyle practices and behaviors that are related to their religious beliefs, 2) coherence, or the meaning of suffering that a religion provides, 3) cohesiveness, or group belonging to the religious community, and 4) world view provided by the underlying theology.

The concept of religiosity will also be used numerous times throughout this study. According to Jarvis and Northcott (1987) religiosity refers to attitudinal dimensions such as belief in God, religious orthodoxy, commitment to a faith and seeing one's religion as a source of strength. Religiosity may translate into health-related attitudes andjor into health-related actions derived from the particular religion's prescriptions and proscriptions about behavior. These actions we call health-related behaviors. They are a form of religious participation that has health implications. These behaviors, in turn, make it more or less likely that an individual will become ill or die.

The following section will review literature that illustrates how health practices have been affected by religion. 
REVIEW OF LITERATURE

\section{Health Practices}

The relationship between health and religion has been receiving increasing scientific attention in recent years. One indicator of this interest is the growing number of reviews focused on religious variables that have appeared in the medical and social science literature (Williams 1991). Variables that have been studied include: health practices, social network support, meaning of life, and meaning for the reasons that people suffer. It has been determined in many of these studies that health practices based on religious beliefs have had a positive effect on health (Berkman \& Syme 1979; Medalie et al. 1973; Hannay 1980).

Religions that provide strong directives for the personal lives of adherents tend to result in distinctive lifestyles. For example, strict proscriptions against the use of alcohol and tobacco would result in less exposure to these substances. It is well-known that cigarette smoking is, by far, the single most important risk factor for lung cancer (Troyer 1988). Therefore, these directives would prevent exposure to a potential risk factor.

Henry Troyer (1988) found that the overall rates of certain cancers were reduced in the 4 religious groups that he studied. In critically assessing and evaluating the distinctive lifestyle patterns of these groups he discovered that the rate of smoking was nearly zero, and that the rate of 
lung. cancer in these groups was correspondingly strikingly low.

Troyer also discovered that the groups he examined had strong prohibitions against premarital and extramarital sex practices, and marriages were extremely stable. Their low rate of cervical cancer is consistent with promiscuity being a strong risk factor. These observations are consistent with some of the commonly advanced risk factors for cervical cancer (promiscuous sexual practices of the male and female, and early commencement of sexual activity. These risk factors were almost entirely absent from the life-styles of all four groups that he studied, which largely explains the very low rate of cervical cancer (Troyer 1988).

In another study schiller and Levin concluded that certain dispositions about preventive practices, attitudes toward physicians and health care, reactions to pain, and beliefs about the relation of the body to a spiritual being were all positive factors in determining health care utilization. Although, these dispositions vary by religious affiliation, they do provide avenues by which religion exerts indirect effects on utilization, whether they be preventive, curative, or palliative (Schiller and Levin 1988).

\section{Social Cohesiveness}

There have been several studies that have examined the relationship between health and religious involvement. Most of the research appears to support the hypothesis that ties to 
a religious group provide access to emotional, cognitive, and material support. If an individual feels cared for the likelihood of experiencing certain illnesses may be reduced (Byrne 1979). For instances, these connections are reported to have reduced rates of mortality (Berkman and syme 1979), lowered levels of myocardial infarction (Medalie et al. 1973), and resulted in higher scores on physical symptom checklists (Hannay 1980)

Another way that religious involvement or the social network may be represented is by attendance at religious services. Ferraro (1991) asserts that religious services are social rituals, and through these rituals religious traditions affirm and enact beliefs and world views. Religious services also may instill special moods and motivations, and identify prescribed and forbidden courses of action.

Not only does attendance at religious services offer motivation for certain behavior, and affirmation about beliefs, but the minister may also offer strength in the face of the unknown in a time of crisis. For instance, a visit from a minister prior to surgery often gives the patient a feeling of well being during a frightening situation. In a situation where people lose control, such as surgery, people may tend to depend more on a belief in God (Byrne 1979).

In an extensive review of religious factors in epidemiological studies dating back to the early 19 th century, Levin and Vanderpool found that in the majority of these 
studies infrequent religious attendance was regarded as a consistent risk factor for morbidity and mortality of various types.

Yet in another study of a survey of symptoms conducted by D.R. Hannay (1980) in Glasgow, Scotland, it was found that the prevalence of symptoms of ill health was related to religious commitment. This relationship did not depend on denomination or creed, but rather on whether people participated actively in their religion as opposed to having a passive commitment. Those whose commitment was passive had significantly more symptoms whether physical, mental or social.

For minority groups who were distant from their cultural base, an increase in religious observance seemed to act as a stabilizing factor. This stability appeared to be associated with better health as assessed by a lower prevalence of symptoms of ill health (Hannay 1980).

Another comprehensive study by Levin and Vanderpool (1980) reviewed over 200 research reports written over a twocentury period and found generally a positive relation between religiosity (e.g., church attendance) and physiological/mental health (e.g., lower rates of cardiovascular disease, hypertension and strokes, colitis and enteritis, general mortality, and cancer of the uterus and cervix).

A longitudinal community study of 720 adults examined the effect of religious attendance and affiliation on psychological distress (Williams 1991). This study found that 
religious affiliation is unrelated to mental health status; however, it did find that religion buffers the deleterious effects of stress on mental health. That is, in the face of stressful events and physical health problems, religious attendance reduces the adverse consequences of these stressors on psychological well being.

Thus religious involvement may constitute an array of functions and processes that are known to be associated with health. These functions and processes result in positive effects for health such as social support, stress-buffering, and positive mental attitude, among others (Levin 1987).

\section{Coherence}

Religious devotion activates a special meaning system to make sense out of life. In particular, an emerging literature on the subject points to prayer and devotion as significant factors in many persons' perceptions of their quality of life (Trier 1991). In an intriguing double-blind experiment Byrd (1988) found that within a coronary care unit patients for whom intercessory prayers to Jesus Christ were offered experienced significant reductions in the need for antibiotics, diuretics, and other therapies compared with a control group of patients for whom prayers were not offered. In addition, Koenig, Smiley, and Gonzales (1988) reviewed several clinical studies of prayer and healing in hospitals and found prayer associated with improvement in patients' overall conditions. They also researched the importance of 
religious faith and prayer for the mental and physical health of the elderly and discovered it to be significant (Trier 1991)

Walsh (1980) noted the importance of a religious outlook on life in his study of stress associated with immigration and assimilation. He hypothesized, that those experiencing the most difficulty resolving the anomic experience of assimilation, will evidence higher blood pressure levels than those who are able to make a smoother transition. He also hypothesized that smoother adjustment is made possible for the immigrant who has a religious outlook on life. He concluded that his data seemed to support the contention that such an outlook is an important stress-reducing device. He states:

It is our assumption that a religious outlook on life is a valuable resource for the immigrant in his collision with his new world and its alien culture. Since immigration is a life change that is perhaps more total in scope than any other, it is suggested that religion has a certain illness or disease preventing power, especially for the immigrant (Walsh 1980).

In a similar vein Hannay (1990) says that church attendance is related to fewer symptoms of physical and mental ill health. Yet another finding by Graham and co-workers found that higher church attendance is related to lower blood pressure (Jarvis 1987).

Still further literature about coping, stress, and adaptation provides another link between religiosity and psychosocial distress. Glik asserts that adherence to religious beliefs can be defined as a cognitive emotion- 
focused coping strategy, as techniques of cognitive reappraisal, denial, or adoption of meaningful explanatory models for stressful life situations can buffer the consequences of stress (Glik 1990). She cites studies done by Antonovsky 1980, Lazarus and Folkman 1984 as evidence that certain coping strategies serve to buffer the consequences of stress (Glik 1990).

Numerous studies within the quantitative sociological, psychological, and gerontological literatures have reported that spirituality (religious devotion), or one of the dimensions of spirituality, has a positive relationship between measures of spirituality and happiness, social adjustment, or life satisfaction has been shown (Glik 1990). Ferraro (1991) also notes a growing scientific evidence for a positive link between religiosity and physical health status, although these studies are fewer in number.

\section{World View}

Peter Berger asserts that society is the guardian of order and meaning not only at the level of social structure, but at the level of the individual consciousness (Berger 1967). Spirituality modifies perceptions of distress associated with physical suffering, often giving hope to the individual. Many scholars have commented on the world view or 'world construction' aspects of religion. For example, the lack of a consistent world view to explain events and to justify one's values and lifestyle can be disrupting and 
disorienting. Levin and Vanderpool suggest (1987, 1373) meaningful associations between a health-related outcome and a religion variable can obtain only if the religious indicator taps a construct or experience or phenomenon that is shared by the entirety of the population, sample, or subsample under investigation.

Deborah Glik (1988) found in analyzing characteristics of two different types (1) Christian, Pentecostal, neoPentecostal or 'charismatic' healing groups and (2) 'New Age', or metaphysical healing groups in the Baltimore area that the incorporation of explanatory models, social roles, myths, and symbols into the social, ideational, and ritual context of spiritual healing is essential to its therapeutic effect, and that spiritual healing exemplifies a symbolic healing system.

This review of various religious groups and their health demonstrates the salutary effects that religion can have on individual and group health. With this background presentation, we can now turn to the soviet Pentecostal who are yet another example of a religious group whose health is affected by their beliefs.

In order to understand the relationship between health and religion in this population, we will first look at the development of their particular belief system, Pentecostalism, its spread to the Soviet Union, and their move to the United states. 
CHAPTER II

BACKGROUND AND OVERVIEW

THE DEVELOPMENT OF PENTECOSTALISM

Pentecostalism was born in the United States less than a hundred years ago. Although no one knows how large the movement really is, scholars estimate that there are several million adherents in the United States and possibly 100 million worldwide. Over the years more than three hundred Pentecostal denominations have sprung up in this country alone. Most are quite small, yet the two largest, the Assemblies of God and the Church of God in Christ, each claim more than two million domestic followers and additional millions in other parts of the world (Wacker 1986).

Although historians debate the exact origins of the movement, most agree that it grew from the union of distinct traditions within evangelical protestantism in the late nineteenth century. The core of evangelical protestant belief was the proclamation that God had provided salvation for the human race through his son Jesus Christ, who had made possible the restoration of a fellowship with God that had been broken by sin. The restoration of fellowship with God is known as the "salvation experience." within this movement there was a widespread conviction that the salvation experience ought to 
be followed by another landmark experience known as the "baptism of the Holy spirit" (Wacker 1986). The baptism of the Holy spirit refers to an emotional experience of divine power, where the presence of the Holy spirit fills the individual. The Holy spirit, (or the "spirit of God") is also known as the Spirit of Pentecost, and is the third Person of the Holy Trinity. The christian concept of a triune God consists of God himself, Jesus his Son, and God's spirit, referred to as the "Holy spirit."

The Pentecostals believe that this baptism of adults, which is supplemental to water baptism, is a necessary foundation for personal holiness and, more significantly, a prerequisite for the receiving of certain "gifts" from God. The Pentecostals believe that God can give humans certain "gifts" or spiritual attributes, that include the ability to speak in tongues (glossolalia), the ability to heal, the ability to drive out evil spirits and other so-called gifts. The Pentecostals find support for this belief in a portion of the Bible called Corinthians (Kolarz 1962).

Near the turn of the century, the concept of spirit Baptism combined with numerous reports of miraculous healing experiences to fuel a powerful expectation that God's return was at hand. This stress on the miraculous is one of the chief characteristics of the Pentecostals who are a community of faith-healers, prophets and mass evangelists (Wacker 1986). 
In this context of mounting religious fervor, many believers began to look for an indisputable sign, or proof, that they had received the baptism of the Holy spirit. In 1901 Charles Fox Parham, came to the conclusion that speaking in "unknown tongues" was the coveted evidence they were seeking. Five years later a black holiness preacher named William J. Seymour carried Parham's message to Los Angeles, where he ignited the Azusa street revival and, it turned out, the modern Pentecostal movement (Wacker 1986).

All of the major Pentecostal denominations emerged in the next two decades. Through the influence of persons who had visited the Azusa Mission many groups in the Southeast joined the movement between 1907 and 1911, they included the predominantly black Church of God in Christ; the church of God; and the Pentecostal Holiness Church. Soon another sect, the Assemblies of God joined the movement. They organized in 1914 (Wacker 1986).

A doctrinal dispute in the Assemblies of God over the nature of the Trinity, or the triune God, prompted the formation of numerous unitarian or "Oneness" groups throughout the Midwest. The largest of these now call themselves the United Pentecostal Church, International, and the Pentecostal Assemblies of the World. In the 1920's Aimee Semple McPherson also broke from the Assemblies of God to establish her own denomination in Los Angeles, the International Church of the Foursquare Gospel (Wacker 1986). 
In the early days Pentecostal churches often named themselves Full Gospel Tabernacles, which meant that they preached the "full" gospel of personal conversion (belief in a personal God), baptism of the Holy spirit with the evidence of unknown tongues, divine healing, and the promise of the near return of Jesus Christ.

It has been proposed that the doctrine and practice of divine healing, along with the doctrine and practice of speaking in tongues, has been the enduring backbone of the Pentecostal tradition. Although only a small minority of Pentecostal have ever claimed a miraculous healing themselves, virtually all would insist that God heals any believer whose faith is sufficient (Wacker 1962).

\section{Nineteenth-Century Background}

Among the legacies of eighteenth-century German pietism was a conviction that the New Testament miracles did not cease at the end of the apostolic age, but continued to be available for the comfort and edification of the church in all ages. In 1852 a pietist pastor named Johann Christoph Blumhardt established a medical retreat. He believed that original and personal sin was the principal cause of illness and claimed that repentance was necessary for healing for the body as well as for the soul (Wacker 1986).

He did not, however, believe that sin was the whole story, for demons sometimes torment the bodies of the faithful. Although, exorcism, or removal of demons, ought to 
be a regular feature of the healing ministry of the church, however he was careful to say that God might, in his sovereign will, withhold healing (Wacker 1986).

Modern Pentecostals commonly distinguish themselves from other Protestants by the doctrine and practice of speaking in tongues however, an overview of the early literature leaves little doubt that in the beginning divine healing was, if not equally distinctive, at least equally important (Wacker 1986). Given the promise that God always responds to a genuine prayer of faith, the persistence of illness could be explained only two ways: either one's life was impure or one's faith was shallow (Wacker 1986). From here it was only a short step to the idea that truly converted and spirit-filled believers were protected from illness in the first place. This was the preventative part of the Spirit's work. The therapeutic part was divine happiness and health.

The role of demons in human affairs was another major concern in the practical healing theology of early Pentecostalism. As already noted, in the nineteenth century many evangelical Protestants assumed that demons could oppress or even inhabit the human body. Pentecostalist continue to view demons as a constant threat, the direct and immediate source of many afflictions. Consequently, they often construe divine healing as exorcism, or removal, of the oppressing demon (Wacker 1986 523). 
These, then, were the principal, formal and practical concerns of the theology of divine healing in primitive Pentecostalism. Within this general context, however, there was widespread disagreement about the proper attitude toward medicine and physicians. Many felt that medical care was an inferior yet morally permissible alternative for Christians of weak faith, but the majority urged total avoidance of professional help, and many displayed overt hostility toward the medical and especially pharmaceutical professions. The reasons for these attitudes included resentment against the higher social status of physicians and druggist, but theological assumptions also entered in. Pentecostals considered physicians to be intruders upon a sacred realm. In addition, patent medicines were viewed as evil because of the alcoholic and narcotic ingredients that they contained. In other words, they believed the medicines to be unnatural and demonic in origins (Wacker 1986).

The Pentecostal movement as a whole enjoyed modest numerical growth during the mid-century decades. Changes that occurred within the movement after World War II were increased social standing of a typical member and sustained centralization and institutionalized development, (i.e., the opening of Christian schools, orphanages, and retirement homes.) Along with these changes a gradual abatement of healing miracles in Pentecostal worship services and 
relaxation of prohibitions against medicines and physicians took place (Wacker 1986).

Pentetcostals in a Modern World (1960-1985)

The established Pentecostal churches of the 1980's combine supernaturalism and pragmatism. As an example, leaders believe that divine healing of both physical and mental illness is essentially different from any natural form of healing. Still another example of the persistence of the older beliefs is that many of the same practices are still prohibited, such as the use of alcohol, tobacco, and marijuana. An addiction to one of these substances is regarded as a weakness and a predictable result of deliberately sinful choices (wacker 1986).

Thus, Pentecostals believe that God touches their daily lives in miraculous ways particularly in health and illness. One of the main experiences characteristic of the pentecostal movement is a sense of being in touch with God's power-whether through ordinary personal prayers, or more strongly, through various "gifts of the spirit."

Most pentecostals, then, have specific beliefs about health and health practices. Though similar in many respects to the American Pentecostalist, soviet Pentecostals, have different cultural roots. For instance, cultural experiences of persecution have effected their attitudes toward health care utilization. 
The following overview of the development of Pentecostalism in the former Soviet Union will reveal some of the experiences that its adherents have encountered while living there.

DEVELOPMENT OF PENTECOSTALISM IN THE SOVIET UNION

The Pentecostal movement reached Russia a few years after it had emerged, almost simultaneously, in the United states, Britain, South Africa and Scandinavia. Pentecostal missionaries went from these countries to many parts of the world.

However, the Pentecostal movement only began to spread in Russia after the communists had seized power. In 1922 , the Soviet authorities allowed a missionary to enter the soviet Ukraine. Ivan Efimovich Voronaev, an American missionary, a former Baptist, of Russian-Ukrainian descent; was inspired to move to the Ukraine by the American Assemblies of God movement for which he considered himself a missionary.

Thus, from the very beginning, Pentecostalism in the Soviet Union had no connections with the Russian orthodox Church. The new communist government, trying to diminish the influence of the Russian Orthodox Church, gave evangelical Christian groups relative freedom to practice their faith openly and to evangelize. From the beginning of Pentecostalism until the 1917 Bolshevik Revolution, 
evangelicals were persecuted by the dominant Russian orthodox Church (World Relief 1989).

To begin with Vornaev gained most of his converts from the Ukrainian Baptists and Evangelical Christians. These converts came from the republics of the Ukraine and Russian Federation (Lane 1978). Voronaev's intrusion into the camps of the Baptist and Evangelical Christians caused intense rivalry between the sects. By 1926 the Pentecostal movement in the Soviet Union had 350 congregations with 17,000 believers. Soon, however, the unchecked growth was slowed by active religious persecution and any growth that did take place did so clandestinely (Kolarz 1962).

There is no evidence of Pentecostal activities in the thirties, but it is certain that many congregations formed by Voronaev's evangelistic fervor continued to exist. The movement was strengthened in 1939 when a number of small but very active Pentecostal groups of Eastern Poland came under Soviet rule. Two years later the authorities forced the Pentecostals to amalgamate with the Baptists and Evangelical Christians. In August 1945 it was disclosed that 400 Pentecostal congregations had joined the council of Evangelical Christians/Baptists (Kolarz 1962).

In general, the large, easily supervised EvangelicalBaptist-Pentecostal Union, was convenient for the government, but for the believers themselves it was most unsatisfactory (Kolarz 1962). For example, the Pentecostals had to severely 
curtail the practice of their central and most distinctive rituals, i.e., speaking in tongues and divine healing, which caused bitter rivalry and hostility among the members (Lane 1978) .

The Soviet authorities were not neutral in the BaptistPentecostal controversy. They unquestionably supported the Baptists more than the Pentecostals because they believed the Pentecostals could be dangerous fanatics (Kolarz 1962). The attitude of Pentecostals towards Soviet life ranged from noncommittal passivity to outright negation. Pentecostals were not openly hostile to the state, but tried to avoid government service in whatever way possible (Kolarz 1962).

Evidence of the government's hostility toward the Pentecostals was the forced removal from the Ukraine of some particularly successful Pentecostal preachers. Even after the post-stalin amnesty these Pentecostal leaders were not allowed to return to their homeland. In addition, state authorities often believed that membership within the Pentecostal movement was consonant with a negative attitude towards the state (Kolarz 1962). As a result, the government tried to ignore the religious aspect of the Pentecostal movement and to attach disproportionate importance to its hostility to the state, the army, the Party, the trade unions and soviet education. The Soviet officials did not find it difficult to convict Pentecostal leaders in various parts of the country as political criminals. Once convicted the defendants could 
receive prison sentences of up to ten years (Kolarz 1962; Lane 1978).

However, Pentecostalism survived despite its history of persecution and harassment. Originally confined to Ukraine and Byelorussia, it invaded many other parts of the country within a few years. For instance, it was reported that the Soviet press mentioned Pentecostal groups in a large number of provinces and cities of European Russia (Kolarz 1962). Two reasons are given for the spread of this movement. First, numerous conversions were made in labor camps by ukrainian and Byelorussian Pentecostals, and after release from the camps these new converts went to new areas. As a result, the movement ceased to be a predominantly ukrainian one, but also embraced a considerable number of Great Russians (Kolarz 1962) .

Secondly, the Pentecostal faith spread as a result of the deliberate migration of entire Pentecostal groups. Several factors may account for this nomadism, a desire to avoid persecution and to go to new areas where they were unknown, and finally the apocalyptic search for a legendary country where the forces of evil do not rule (Kolarz 1962).

Wherever they are, the Pentecostals make active attempts to spread their faith either through personal talks or with the help of letters be copied and passed on. The communal life of the Pentecostals is intense, some groups meeting three times a week. Their meetings are spent in prayer, singing, 
preaching and the mutual washing of feet, a ritual action particularly dear to them. It is at these meetings that the gifts of tongues, the spirit's gifts of healing, driving out devils and general miracle working are often practiced (Lane 1978). Great stress is also placed on Bible reading both collectively and individually; and despite their low level of literacy they are said to be very knowledgeable in this area (Lane 1978). The members of the sect show a great spirit of sacrifice, and much money is collected at the meetings, most of it to be spent on evangelism (Kolarz 1962; Lane 1978).

The Pentecostals make converts entirely from among the poorer members of the community. In addition, as a dynamic religious body it is also very attractive to young people (Kolarz 1962).

To sum up, freedom of religion was not a matter of choice for Soviet citizens before glasnost. Previous to this time choosing to be identified as Pentecostals resulted in extreme persecution and oppression. This persecution was the justification for most of the refugees emigrating to the United states where refugees are granted entry if they prove a "well-founded fear of persecution." (The Jewish Review 1990)

SOVIET PENTECOSTALS IN THE U. S.

The common factors among all the Soviet Pentecostals is their strong adherence to their religious belief system of 
Pentecostalism and their status as religious refugees. Most of the refugees who have come to the United States since World War II left their countries because of political or ethnic persecution. The Soviet Pentecostal refugees, on the other hand, have emigrated because of religious persecution (World Relief 1989).

The area of the world from which the Pentecostal refugees emigrated was the former soviet Union. At that time it was a federation of 5 republics each inhabited by a different ethnic group. A majority of its citizens lived in the Russian soviet Federative Socialist Republic (RSFSR), the Ukraine and Byelorussia (Eubank 1974). The people who inhabited these republics were slavic in origin and belonged to a similar linguistic group (Gerber 1985).

The majority of Soviet Pentecostal refugees who are presently settling in oregon are from the Ukraine, along with smaller groups who have emigrated from Russia, Estonia, Georgia, and Kazakhastan (World Relief 1989). The majority share an ability to speak Russian and share a similar culture and are referred to as "Christians of the Evangelical faith" in their country. The Soviet Pentecostal are distinct from other Evangelical groups, with whom they are associated in the Soviet Union. This distinction is the result of their religious emphasis on speaking in tongues, beliefs in healing, and the baptism of the Holy Spirit (World Relief 1989). 
, The more recent Pentecostal refugees from Russia and ukraine were drawn to oregon by the actions of the old Believers' community in Woodburn, oregon. The old Believers are a religious group who immigrated to the United states from the former soviet Union via Brazil in the early 1960's in order to escape persecution (Colfer 1985). Their particular ideological focus has encouraged them to keep themselves socially aloof, to cultivate exclusivity and even isolationism. old Believers started their religious life as defenders of the Russian spiritual heritage against the imposition of the Greek tradition and, ever since, their religious life has been devoted to preserving this heritage. Not only in their religious life but in all their everyday pursuits they have tried to uphold old Russian habits and customs, as for example, certain styles of dress and general appearance. Centuries of persecution because of this mission is closely allied to the strong feeling of group identity, of being a community different and apart from the rest of society (Lane 1978) .

The same characteristics that made the old Believers distinct in the former soviet Union transferred with them to America, where their lifestyles and belief system have remained for the most part unchanged (Colfer 1985).

Initial links between the two communities consisted of a common language, culture, and an intense hatred of the soviet 
government. In 1977 the old Believers offered haven to the Pentecostals in the Soviet Union who were under persecution. However, the Soviet emigration policy remained unchanged, for ten years, and as a result the old Believers' offer went unanswered. Then the soviet government, as a result of glasnost suddenly began allowing large numbers of Jews and Evangelical Christians to leave the country.

As a result in 1989 , the community of Woodburn, Oregon, began experiencing an influx of soviet Pentecostal Refugees. The first 100 arrivals were relatively easily absorbed into the community; however, as more arrivals came the economic and housing of that small community was soon overwhelmed. In addition, differences in their theologies began causing strife among the two groups, and this resulted in the formation of separate communities. Soon after this separation many of the Pentecostals moved to the Portland metro area where there were more economic opportunities and available housing.

Many of the refugees who were born before World War II have had only a few years of elementary education, although most of the younger generation has completed high school and occasionally some kind of vocational or trade school. In America, as in the former soviet Union, the majority of them are employed in blue collar jobs, factory workers, farm workers, heavy equipment operators, truck drivers, construction workers, electricians, plumbers and mechanics. Because of their limited education and recent immigration to 
the United States, very few can speak English (World Relief 1989).

The Pentecostals from the former Soviet Union are also very serious. In addition, they have strongly held religious views, such as the concept of living apart from a sinful society, proscriptions against drinking or smoking, and application of standards of holiness to their personal appearance (i.e., the women do not use makeup and are careful not to wear seductive clothing). Generally they have a strong sense of community and tend to place great value on personal relationships (World Relief 1989).

The Soviet Pentecostals immigrating to the United states have arrived with varying degrees of health problems according to State Refugee Coordinator, Ron Spendal (Spendal 1989). Problems that are often mentioned by the refugees and health care workers include heart problems, abdominal hernias, and dental cavities. It has been suggested by both health care workers and the refugees themselves that these health problems were the result of extended deprivation of adequate medical care, non-existent preventive practices; poor nutrition, and inferior lifestyle practices (i.e., extremely hard physical work and substandard living conditions and persecution).

Soviet Pentecostals have distinctive health practices which they bring with them. World Relief (1989) reports that Soviet standards of personal hygiene are generally lower than most Americans. In addition, Soviets tend to have fixed 
opinions about conditions that they believe may cause illness. For example, they are fearful of drafts, and in warm weather may prefer to sit in a stuffy room rather than open a window for a fresh breeze. Children are bundled in multiple layers during the winter and are reminded to put something on their feet indoors to guard against cold floors (World Relief 1989).

In America the refugees have to assume responsibility for provision of medical care plus other daily provision. This is quite different from their former lives in the soviet Union where the medical system, although fraught with inadequacy, provided care without cost (resolve with later information). Along with this responsibility comes the freedom to make choices. However, the variety of choices that North Americans routinely make even on a daily basis will initially intimidate most refugees. They will learn that North American life is full of decisions, which can prove to be emotionally exhausting, this is particularly true for refugees who emigrate as older adults (World Relief 1989).

The health care system in the Soviet Union, though free, is looked on with distrust by the Soviet Pentecostal, based on past experiences. Consequently the traditional choice of health care often chosen in the past was based on trusted folk medicines and treatments (Geertsen 1975). This is still true of the refugees, for a soviet Pentecostals may hesitate to take medicine or visit the doctor when ill, preferring to apply home remedies (Horld Relief 1989). 
, In summary, the Soviet Pentecostals, who have recently moved to the United states respond to the world quite differently from persons who reject supernaturalism. After decades of religious persecution they have arrived here in varying degrees of poor health. The fundamental religious beliefs to which they adhere, provide clear directives for a lifestyle and a strong social support system. Both of these factors influence their health practices and attitudes, which ultimately effect their health.

Therefore, data was collected to explore more deeply the health consequences of this relationship between their religious beliefs and their health practices and attitudes. 
CHAPTER III

METHODOLOGY

The literature was reviewed to provide a supporting framework of general cases in which religion has positively affected the health of various groups in four specific ways, (health behavior, cohesiveness, coherence, and theodicy).

\section{DATA COLLECTION}

This investigation used data from twenty-five in-depth interviews obtained from both the Russian refugees and those who work closely with them. I began by employing a purposive sample of key individuals. Then, based on these interviews, I contacted other individuals using a snowball sample as more data was needed to complete the study.

The interviews that I conducted were generally one hour in length, although some were longer. They were conducted over a nine-month period of time.

My initial contact with the community was through a single, young man in his early to mid twenties. He is a Soviet Pentecostal who moved here with his family from Georgia about nine years ago. He is currently a pre-med student planning to pursue a medical degree. He serves as interpreter for one of the large hospitals in the area. He speaks fluent English and was chosen as a liaison between one of the Soviet 
Pentecostal Churches and the American Church in which they worshipped for a period of time. Having lived in America for several years and yet working closely within the Pentecostal community has given him much insight into both cultures. I interviewed this individual for over an hour. This interview was then followed by several telephone conversations over the next six months.

A married, forty-year-old male that I interviewed moved here with his family of seven from the Ukraine less than three years ago. He has been working as a janitorial assistant, but plans to become a partner of the same janitorial business within the next few months. He was trained as an engineer in college in Russia but because he refused to renounce his Christianity he spent the next several years in exile, many of them in siberia. He and his family were finally allowed to emigrate and through many trials eventually reached the United states. They are enjoying all the freedoms that are offered here, particularly their right to practice their christianity without oppression. This interview took place over coffee in a restaurant. His friend, an American, and soon to be partner, accompanied him and interpreted when problems in communication developed. The interview lasted for approximately two hours.

Another person interviewed was a married, female health care worker, in her early forties. She is the wife of a pastor of one of the large Soviet Pentecostal churches in the 
area. She works at one of the large clinics in the area and also has many close friendships within the soviet Pentecostal church. This interview took place over the telephone, but I had met her previously at the airport when several children arrived in Portland to be evaluated for radiation exposure.

still another interview lasted well over an hour. This was with a young woman who is now a caseworker, who is herself a Soviet Pentecostal in the Portland area. She is also a Soviet Pentecostal who has been here less than three years. She is a mother of two young children and a regular worshipper at a church in Portland. This interview took place at the agency at which she worked.

\section{LIMITATIONS AND ADVANTAGES}

I chose the open-ended interview format because of its flexibility. Data was gathered to answer initial questions; then, while gathering this data, further questions were asked. It meant contacting many different individuals in order to get information for the investigation. Sometimes while pursuing a single question it was helpful to ask several different questions because findings did not address the issues I wished to explore; this often led to further insights that, in turn, evoked further research questions. The flexibility of this process led to more depth and breadth than would the rigid application of a more limited research methodology. 
However, there were some drawbacks. One limitation was that these data were not strictly comparable. For example, the same question was not always asked of persons interviewed early in the research as were of those interviewed later. For instance, the significance of some beliefs and actions were not discussed until later in the study. This made it difficult to retrieve comparative data from early notes, since the data were not initially perceived to be significant enough to record.

The foremost reason for choosing an open ended style of data gathering is that it allows more probing by the interviewer to grasp the meanings of a situation for the participants themselves. Furthermore, in-depth interviews yield firsthand insights into the life of the people studied. There was some difficulty in collecting data on this population, however, for two reasons. Initially the language barrier appeared to be almost insurmountable. However, as I interviewed more people who spoke even a limited amount of English, I was referred to others who were more fluent in their communication.

A second inherent problem was the political system from which they emigrated. Because the Soviet political system was so oppressive to the refugees, they developed a suspicious nature toward anything relating to institutions or to inquiry about their values or beliefs for fear of persecution. In addition, they support the concept of living apart from sinful 
society. Therefore, if you are not identified as one of their group you may be viewed as an outsider and not to be trusted. 


\section{CHAPTER IV}

\section{FINDINGS}

\section{HEALTH STATUS WHEN ENTERING AMERICA}

Previously, the Soviet refugees, were sent for emigration processing to either Rome or Vienna where a thorough health screening was administered as part of the emigration process. In an effort to accelerate the emigration process, due to the fear of possible future restrictions either by the soviet government or limited quotas in the United States, many of the recent refugees have sought to fly directly from Moscow to America. It is felt that the removal of the health screening process has allowed many refugees with chronic health problems to immigrate to America.

Although the immigration process has been accelerated refugees entering Oregon must receive a health screening to assess their general health status and to identify any treatment needs that they may have (FFY 1989 Report). The refugees' sponsors coordinate and assist the refugees in obtaining this health screening which is administered at the International Refugee clinic. Sponsors of the refugees include agencies such as SOAR and Lutheran Family Services, church groups and individuals. 
The influx of soviet refugees arriving in oregon has presented health service providers with an unfamiliar ethnic group. This in turn means that health screening has to be more thorough due to a lack of familiarity with endemic problems within geographic regions. Also Soviet refugees present a greater than historically experienced level of need for medical assistance (FFY 1989 Annual Report 1990).

The most common complaints voiced at the initial health screening are those of heart and cardiovascular problems. In addition to heart and cardiovascular problems other ailments include abdominal hernias (among the males) and the prevalence of dental cavities.

A poor diet, little exercise, and lack of preventative care are blamed for many of the heart and cardiovascular problems. Foods high in fat and limited supplies of fresh fruits and vegetables, the custom of using salt for a preservative for food storage, plus inadequate amounts of exercise and an inadequate and often inaccessible health care system are viewed as major contributors to the prevalence of these problems among the refugees.

one problem found among working male refugees is uncorrected hernias. These male workers with abdominal hernias range from middle-age to old and have worked very hard all their lives in physically demanding occupations. It was suggested that the hard physical labor and lack of preventive 
care have been contributing factors for this condition (Interview \#17).

The prevalence of dental problems both in adults and children are attributed to two causes, poor diet and lack of preventive care (Interview \#17).

This is because the dental treatment is so painful in the Soviet Union, where there is little anesthetic and ancient equipment and preventive measures in dental care are almost nonexistent. Because of the extreme pain that the patient has to endure when receiving dental work, they delay making appointments, trying numerous other remedies before ever seeking help from a dentist. Therefore, upon arrival in America, many have to have extended dental work performed.

The Soviet Pentecostals unanimously agree that inferior health care in the Soviet Union is to be blamed for much of their poor health. The health care system has been increasingly criticized for its antiquated and inaccessible facilities, limited physician knowledge, low quality of care, bureaucratic knots, shortage of medical supplies, and unsterile conditions. First, the hospitals that are located only in the large cities, are aging structures with antiquated equipment and technology. Secondly, ten percent of the 350,000 physicians recently tested were characterized by Minister of Health Chazov as only "provisionally" qualified to take care of patients (Schultz and Rafferty 1990). Thirdly, physicians have little time to render patient care or to study due to time limitations and restricted and parochial medical information. Fourth, extensive paperwork is required before admittance to a hospital and it also consumes much of the time 
that a patient spends during an outpatient visit. Fifth, patients treated in the system are often required to pay doctors and nurses under the table in order to assure that medications be administered or before an operation can be performed. This is done by the patients in an effort to overcome bureaucratic obstacles and short supplies (Schultz and Rafferty 1990; Interview \#17). Finally, lack of sterile conditions are a cause of concern for those who are hospitalized (Interview \#17). For example, disposable equipment is rare, and most equipment is scarce. schultz and Rafferty (1990) report that staff are routinely limited to two to three reusable hypodermic needles and one syringe per shift.

As a result of these conditions refugees express concern about the benefit gained in seeking health care from the medical system there. One refugee responded:

Basically about the only advantage you gain upon admittance to one of the hospitals was that you had an excuse to not work for a period of time and get some badly needed bed rest (Interview \#6).

This feeling was reinforced by the Minister of Health who acknowledged that many hospitals are "little more than places to sleep," and lengths of stay average 17-18 days just to be diagnosed (Schultz and Rafferty 1990).

One positive feature of the medical system in the former Soviet Union was the mass immunization programs that are available in their school system. As a result, most of the 
children and younger adults arrive in America well immunized against infectious diseases.

HEALTH PRACTICES AND THE SUPERNATURAL

Soviet Pentecostals adhere to a very conservative system of beliefs that is different from that of most of mainstream American Christianity. Central to their belief system is that life is ordained by God, (i.e., good health and happiness are more likely to be achieved by those who keep God's word). Accompanying that belief is the view of the human body as the temple of God. Based on the Biblical passage I Corinthians $3: 16$. In agreement with these beliefs which they interpret to mean that there is an individual responsibility to maintain the body in a respectful and healthy manner. Some of the respondents, explained their practice of abstaining from particular habits (i.e., smoking and drinking alcohol) that were detrimental to the body, for in spiritual terms, "Your body is the temple of God" (Interview \#5).

This relationship between health practices and the supernatural suggests the basis for the Soviet Pentecostal's behavior such as refraining from health risk factors or in directed behavior that is considered conducive to better health. Thus, they blend health practices and religious beliefs into a single therapeutic approach and do not separate the natural from the supernatural. 
Proscriptions

Resoluteness of their faith combined with the belief in personal holiness contribute to the Pentecostals' willingness to adhere to certain practices. Proscriptions of unhealthy behavior include the use of tobacco, alcohol, and other harmful drugs. In addition, multiple sexual partners and promiscuous sex are prohibited. According to one health care worker: "This is especially emphasized now in the face of the AIDS epidemic that is sweeping the world" (Interview \#5).

\section{Directed Behaviors}

Fasting is also a preventive measure, because--like prayer-it gets one better in touch with God. An advocate of fasting explained:

You see, fasting doesn't change God..... What it does is it changes you--the person that fasts. The main thing is you become more spiritually attuned or aware of God... You're showing God.. you want to hear from Him-(Interview \#3).

Another health practice mentioned by several of the respondents. They urged close interpersonal relationships, especially with fellow believers. One member said:

You can protect your body...by being in contact with people and having loving relationships with people, and not just living closed in by yourself-but you must reach out to other believers (Interview \#5). 
THE PRACTICES OF PRAYER AND DIVINE HEALING

ON HEALTH CARE UTILIZATION

Many Soviet Pentecostals claim knowledge of spectacular cures, either through the specific effect of the emotional healing services or through the power of prayer (Interviews \#3, \#5 and \#12).

They do not, as a religious group, discourage blood transfusions and other types of medical treatment. since church members believe that, "God's methods are sometimes through men" and that "God put doctors in the world and gave them their skills," it is permissible to seek medical assistance. They pray often for God's hand to guide the physician as he treats the patient.

For serious illnesses in particular, professional medicine and seeking divine healing are used in combination. Hence, church members hold both scientific and religious beliefs about the causation and treatment of illness simultaneously, without any apparent conflict. As stated by one refugee:

In serious illnesses, members do not have to choose between breaking their religious principles by calling the doctor and refusing medical treatment altogether (Interview \#1).

\section{Divine healers}

Accepting the Bible as the literal truth, the soviet Pentecostals officially support the idea of divine healing based upon Biblical passages indicating that some people have 
the power to transmit the healing forces of the Holy spirit. Pentecostals subscribe to a belief that the devil causes illness and that even for such afflictions as mental illness, blindness, dumbness, and epilepsy a person could be possessed by evil spirits. Second, they believe that healing can be obtained through faith the same way as salvation from sin. Thus, in the case of divine punishment, the afflicted person must make contact with God either directly or indirectly through an intermediary such as a faith healer (Interviews \#4 and \#5).

The Soviet Pentecostals claim that healing miracles are performed by certain members of their group who have been given the various gifts. These miraculous healings are performed by the healers who are called to pray and lay hands on the ill person. One of the refugees stated:

It is critical that "the person" have the gift of healing, because if he does not, it makes the person who is not healed look as if he either lacks faith, or is unworthy of healing in some other area of his life. For this reason, they are very careful to make sure that the person possesses the gift of healing so that the believers avoid as much confusion as possible (Interview \#5).

The time at which the believer calls upon the healer to pray for them is different from believer to believer. For some, it is before they go to see a physician. For others it may be mid-course of an illness, and for still others it may be when they are given the word that their illness is terminal. According to one refugee: 
It is all a matter of faith, you must believe that God is going to answer your prayers. This is critical, for $\mathrm{He}$ is willing to answer your prayers to the degree in which you believe on Him (Interview \#4).

\section{Surgery: Confirmation of Belief}

Many refugees come to the America demanding surgery to make them feel better, particularly if they have abdominal hernias or heart problems. This demand for immediate healing via surgery is based on the belief that their immigration to America was the result of an act of God and miraculous healing is but one more step confirming thighs belief. A case worker confirmed this stance:

Especially when it is time to get a job, they have worked very hard all their lives and do not feel well and believe that our advanced medical system, particularly surgery will make them feel better. When it doesn't make a marked improvement, the refugees get very discouraged (Interview \#1.7).

Although most Soviet Pentecostals believe in surgery there are a few who do not like any kind of invasive procedure and refuse to have it. According to one of the respondents, (Interview \#17) in two or three cases, women had been diagnosed with lumps in their breasts and the doctor called them personally and asked them to come in. They refused to do so, saying that: "I do not believe in having a knife to cut into my body." These refugees however are the exception and not the rule. Most are compliant with the physician's decision to perform surgery when needed believing that this is 
God's will and that He will guide the physician's hand (Interview \#4).

Divine healing is a central aspect of the Pentecostal church tenets. It is preferred because it offers the advantage of providing both spiritual and physical healing. The Soviet Pentecostals feel that doctors often fail to treat the whole person, emphasizing that emotional and spiritual, as well as physical aspects, should be treated (Interview \#6). In addition, divine healing is also believed to work in many cases where orthodox medical practices fail (Interview \#1).

Therefore, most church members hold both religious and scientific beliefs about the treatment of illness simultaneously, without any apparent conflict, but their preference is for divine healing (Interviews \#5 and \#7).

\section{Health Care Expectations Affect Attitudes}

As stated earlier the Soviet Pentecostals believe that their immigration to America is an answer to their prayers. So, in spite of their leanings toward faith healing, they come to the America with great expectations of our medical system. These expectations affect the patient's interactions with health care providers dramatically. For instance, one of the first Americans that each immigrant meets is a physician. From the immigrant's perspective, it is a memorable, if not always amicable, encounter. As a rule, the refugees begin by being very cooperative and compliant based on the expectations of our medical system. 
Unfortunately, these expectations are soon dampened by the long waits at the refugee clinic, perceived impersonal attitudes of the physicians, and delayed response of the miracle cure that they are expecting either through the drugs they are given, or the surgeries they undergo (Interview \#17).

There are long waiting lists which cause the refugees much frustration. They are also very disappointed with the physicians at the clinic, they feel they are impersonal, and for most do little to help them. Unhappy with the refugee clinic because of unmet expectations (they expect magical things to happen to them here) they become discouraged and become unwilling to follow the doctor's directions. Instructions to change their diet, exercise more and lose weight are met with noncompliance.

In addition, the long waiting lines, and perceived impersonal attitude of the attending physician prompts them to return to the familiar cures that have worked somewhat well in the past. "They say why go to a doctor, we have to wait in very long lines, and it is very expensive." They go back to the physician only if these alternative methods do not help.

HERBAL MEDICINES, RELIGIOUS BELIEFS AND HEALTH CARE

The Pentecostals believe that God placed all the plants on earth for the use of mankind. This belief is based on a Biblical passage that tells them that there is a ready supply of plants for both provision and medical healing (Hebrews 6:7). A health care worker who works closely with the refugees states:

When heart problems occur in the Soviet Union the people simply go to the woods and obtain a herb known as veronia that would give relief. However since their arrival in the United states they have been unable to find this plant until recently when 
it was located in a local herbal store. Its use is widespread among the refugees. They view this plant and its use as a gift from God and claim the medicinal benefits that He has proscribed to it for their ultimate use and good (Interview \#5).

There are also a number of other culturally-based selfcare measures to which they may turn (Interview \#17).

These include cupping, or a paper that is dipped in mustard and applied to the chest or/ back and that leaves a very, red, red spot on the body. This treatment is used even for the heart. Hot milk and honey for throat problems, also tea with lemon for a number of different ailments. Leafs from the "kaleepa" tree boiled in water and then inhaled for respiratory problems. And, still another, putting blood suckers behind the ears for sucking blood from the head, in order to relieve high blood pressure (Interview \#17).

The Pentecostals' orientation toward natural medicine is a valued cultural tradition as well, and the knowledge is passed from one generation to the next. One respondent stated:

The Soviets have a very strong belief in the use of medicinal herbs. Culturally it has been a tradition for either the parents or grandparents to teach their children where and how to find these plants. This is very important so that the information might be passed down through the generations (Interview \#6).

Furthermore, they believe that there should be a balance maintained in treating the body, particularly in the case of illness. As expressed by one respondent:

You should not treat just one part of the body with a drug, rather healing should be sought for the whole body. Remedies for illnesses such as the flu or a cold would be treated with extended bed rest, a combination of herbal teas, perhaps homemade jams, and various inhalation treatments to help the whole body heal (Interview \#6). 
Another alternative method of treatment that they highly advocate is that of massage. One female refugee stated, "I often seek treatment from a massager." Both massage and herbal medicines improved her health marketedly two different times. She stated that: Massage therapy was used as if the massager was actually rubbing the illness from her body. However to be effective, prayer and belief must accompany the natural treatments (Interview \#4).

In summary, the Soviet Pentecostals approach health and illness through a variety of factors that include the interrelationship of health practices and religious beliefs. In addition, their health is affected by interpersonal relationships with other believers. The following section describes this relationship more clearly.

\section{COHESIVENESS}

It is widely acknowledged (Scotch, 1963; Williams 1991) in many cultures that the existence of a social network is important because it provides social support in preventing or recovering from illness. According to Ellen Idler (1987) ties to a religious group provides access to emotional, cognitive and material support, fostering the individual's perception that he is cared for and esteemed.

Further, (Suchman 1964) has established that immigrants who are more parochial and more tied to their ethnic community are more likely to seek help within their own lay referral 
system in their community. This lends a high level of emotional, spiritual, and physical support to members of the ethnic community. According to Coddington (1972) this support usually results in much better health than those without the support system.

According to a report in World Relief (1989) the Soviet Pentecostals' common experiences of hardship and persecution resulted in close interpersonal relationships among believers while in the former Soviet Union:

For Soviet Christians, besides the hardships of life in the Soviet Union, they have had to live in a society hostile to Christians. Therefore, they are used to very close fellowship.

A refugee reiterated this report:

This strong social support system existed in the former Soviet Union as well as here in America. This may have been because they suffered severe oppression and also because in the Soviet Union they all lived very close together in the communities. Plus, most of their social functions were carried on in the churches there as well as here (Interview \#17).

Although one respondent felt that these close relationships have diminished since moving to America, most feel that the Pentecostal refugees still maintain strong communal ties since moving here.

Yes, yes, there was much stronger support there than here. It has changed since moving to America. Although there is support in the churches here, it is different (Interview \#4).

These strong ties to community have been viewed as a negative as well as a positive factor because it appears that 
it has limited their assimilation into American culture (Interview \#8).

That strong communal ties still exist are evident in their regular participation in both worship and healing services. These services provide an important functions both in reinforcement of their belief system and in the individual's perception that he is loved and cared for by both God and fellow believers. As they witness friends and relatives being healed their beliefs are reinforced and anxiety is reduced when they face similar experiences of ill health. This participation then is therapeutic producing a positive perception to believers that they are loved and cared for by fellow believers and by God.

The constant presence of family members of Soviet Pentecostal patients at clinics and hospitals is still another example of the close interpersonal ties that exist in this group.

\begin{abstract}
Patients are often brought to the clinics by at least one family member, and in many cases, by two or three. Frequently, there is one member of the family that can drive, and perhaps another that can interpret. Further, because the mother and father generally have large families with many small children, the children must come along because there isn't any one to stay at home with them while their parents go to the clinic. The accompaniment of others is because they tend to form very close relationships and depend upon each other for mutual support (Interview \#4).
\end{abstract}

Zuckerman (1984) asserts that the beneficial effect of being within a support group can, depending on the strength of the group, assist in times of need. It can also cultivate an 
attitude that gives the individual a helpful perspective with which to face stressful life situations such as an illness. Pentecostals firmly believe that the strength of their relationships with other believers is important and that these relationships do assist an individual in stressful life situations. For instance, in the case of illness they do not hesitate to call on other believers for prayer in healing the illness. This was emphasized by the testimony of one of the recent refugees who experienced a miraculous healing in the Soviet Union, just before moving to the United States, after he had been sent home to die. He states (Interview \#12):

They write paper to my organization that say sorry Paul is sick and very soon die. After one week many people, Christian friends come to my house and pray to Jesus all the time... Jesus come to me and stop at my bed, and he say, Paul, what do you want? And I say, Jesus, please heal me.... he has given me everything, he has healed me.

In summary the existence of the community of believers provides access to a support system that helps to modify or reduce illnesses by loving and caring for each other.

\section{STRESS -- THE COHERENCE FACTOR}

Perhaps the most familiar connection between health and illness on the one hand and psychological and social factors on the other hand can be discussed under the umbrella concept of stress. Stress is defined as "the non-specific response of the body to any demand" (McGuire 1988c). 
The Soviet Pentecostal refugees have experienced various forms of stress-caused illnesses since moving to America. Particularly depression and other forms of mental illness have been evidenced as related symptoms such as headaches, dizziness, chest pain, progressive hearing losses, rashes, and fatigue have appeared in the population (Interview \#17).

Aaron Antonovsky's (1980) broader concept of coherence is useful in understanding how social and psychological factors relate to people's interpretation of stress. Antonovsky suggests a person's sense of power affects whether he or she feels enabled to cope in a given situation (McGuire 1988c). Specific coping responses include modifying the situation by attempts to redefine the situation such as by interpreting something as positive rather than negative (McGuire 1988C).

The Soviet Pentecostals' belief that God is with them in all circumstances and that God is also all powerful, allows an active and comprehensive perspective from which to understand the positive aspects of life and the negative, and health as well as illness. Therefore, the Pentecostal refugee's response, because of his belief that God works in his life for his own good, should normally empower and strengthen him in the face of stressful situations, including illness itself (Interview \#12).

Terrible, terrible life some people give me problems, I have court and I go to solitary confinement for three months. My father and mother have letter saying Paul very soon go to prison for five years because he believe God. But God knows what he is doing, I pray all the time and for me it 
is a very good time, because I have a very special

time of praying.

Since immigrating to America the refugees have been exposed to various forms of psychological stress because of their sudden immersion into a new and alien environment. For example, the refugees have immigrated from a background that, at least in theory, made provision for all their basic needs (i.e., housing, medical care, and work). However, according to state official, Ron spendal, state refugee coordinator (1988) many of the refugees come to America with preconceived and inaccurate perceptions about what North America is like:

The Soviets come to the United States with somewhat of a distorted image because for most of them all they can relate America to is what they have heard over the Voice of America that presents a Disneyland impression of what they are to expect here (Interview \#13).

Another cause of psychological stress is being forced to make unfamiliar choices. McGuire (1988c) hypothesizes that a particularly harmful psychosocial characteristic of modern society is information input overload. She states: "Events and experiences perceived as threats appear to be particularly likely to promote illness" (McGuire 1988c). A sudden change from a society where all your choices are made for you and all your basic needs are provided for into a culture where you are responsible for all your choices and needs can be overwhelming.

Financial stress of unemployment or underemployment also causes stress. This can be a critical issue for an ill soviet 
Pentecostal because unpaid bills are viewed as being irresponsible. Therefore, they may become very sick and despondent because they are unable to pay for seeking professional health care. This was summarized in an interview with a health care worker:

Their reluctance in seeking health care may be because they believe that the way in which you pay your bills is a reflection of your witness. Thus without a job or any means to pay the bills once their assistance runs out he may become very ill before coming to the attention of the medical system (Interview \#1).

As stated earlier, psychological stress may eventually lead to depression and mental illness.

\section{Mental Illness}

Because of the strong negative stigma attached to mental illness it is common for the soviet Pentecostals to go to great effort to protect the family name from 'shame' by avoiding mental health services. This attitude was fostered in the Soviet Union where symptoms of mental illness were attributed to physical causes. According to Brodsky (1988) mental illness was the cause of severe stimatizism and individuals so diagnosed were viewed as "letting down the image" of a happy social society in the USSR.

In the former Soviet Union the Pentecostals' experiences with the mental health professionals were often reported to be abusive. For example, political nonconformity, which the Pentecostal were known for, was characterized as a psychiatric problem that was "treated" with forced commitment to mental 
hospitals. Thus, mental health workers everywhere are often viewed as government officials who are to be feared, disbelieved, and avoided (Brodsky 1988; Interview \#12).

There are differences in the way that Soviet Pentecostals approach illness and the way that Americans do. For example, according to a number of refugees (Interviews \#2, \#1, \#6's) episodes of illness are subjects of daily conversations in the former Soviet Union but illnesses are discussed much less in America .

It is also important to the soviet Pentecostal that he be enlightened by God about the nature of his illness. This enlightment not only assists the refugees in diagnosing the problem but it also provides a way of explaining episodes of illness. For example, it helps to determine if the nature of the problem is spiritual or physical thus locating the problem firmly within the belief system of the group (Suchman 1964).

Thus, if an individual feels his life is out of spiritual order, and is without purpose, he may be a candidate for either mental or physical illness. On the other hand, if he maintains a strong sense of coherence or order to his life, this should enhance the possibility of remaining healthy. Suchman (1964) contends that a person's sense of coherence may ultimately be a key factor in an individual's interpretation of his own life situation or the stress which he is currently experiencing. 
WORLD VIEW

The Soviet Pentecostal's interpretation of his life situation and how it reflects on his health is largely determined by his world view or theodicy. Theodicy may be viewed as the legitimations for life. According to Idler (1987), theodicy draws on religion's traditional provision of meaning for the marginal situations of human life. It asserts meaning where events and experiences seem meaningless.

According to McGuire (1982b) theodices do not necessarily make the person happy or eliminate the suffering; they do however, provide meaning. Thus the ultimate theodicy, when the others fail to satisfy, is that while humans might not know why, God does; meaning exists, but because we are human we are not always able to know what it is. It is satisfying for some persons to know merely that meaning exists, even if they personally do not know what meaning is. Religious involvement operating in this way may act to modify the individual's perceptions of and distress associated with suffering.

Pentecostalism provides a bond between physical health and religious assurance which contributes to the understanding of life's most troublesome moments. It also provides a way of explaining events and experiences; it gives meaning to unstructured and problematic episodes, and it locates the problem firmly with the belief system of the group. 
CHAPTER V

SUMMARY

The purpose of this study was to make available data that illustrated the health practices of the Soviet Pentecostal refugee and how those practices were affected by the religious belief system that they adhere to, that ultimately affects their health.

of primary importance is that the Soviet Pentecostals view their health and treatment of illness through a larger system of beliefs, of which health practices and attitudes are only a part. The professional help-seeking process is marked by their belief in the supernatural. They normally seek divine healing before requesting any assistance from the medical professional. However, because they believe that the medical professional can also be an instrument of God, they are not reluctant to seek their help if divine healing has first been attempted. In addition, they also believe that herbal plants are to be used extensively in treating illness because God has given to them to mankind for their use.

Seeking help often taps group resources for a network of support and mutual care, even though this mutual care varies to some extent. Nevertheless, in relationship to the "all 
important divine healing", other members are committed participants in seeking healing for the sick person.

Finally, a strong link has been made between stress and illness in this community. Immigrants who are left to their own resources to grapple with their own profound life change without a belief in the supernatural and the comforting expression of the church, its fellowship, and its health practices may have a very difficult time which reflects into their health status. Therefore it is important for the medical community to understand the value of the community of believers along with the larger belief system.

In summary, a sociological exploration of the soviet Pentecostalists' particular world view reveals an important relationship to their health. The hypothesis for this study suggests that their health practices are directly influenced by this world view, and the interviews ultimately supported this hypothesis. 


\section{REFERENCES}

Alba, Richard D. 1985. Jewishness in America: ascription and choice. Ethnicity and Race in the U.S.A. London: Routledge \& Kegan Paul, 117-131.

Amick, Steven. January 11, 1989. 4 Soviet families arrive in Portland looking for religious freedom. The oregonian B5.

Amundsen, Darrel W. and Ferngren, Gary B. 1986. Caring and Curing: Health\& Medicine. New York: MacMillan Pub. Co., 41-63.

Antonvosky, Aaron. 1980. Health, Stress, and coping. Jossey-Bass.

Antonvosky, Aaron. 1987. Unraveling the mystery of health. San Francisco: Jossey Bass, Inc.

Bella, Rick. November 23, 1989. Living with thanks every day. The oregonian A1.

Belloc, Nedra B., Breslow, Lester, and Hochstim, Joseph R. August 10, 1970. Measurement of Physical Health In $A$ General Population Survey. American Journal of Epidemiology, Vol. 93, No.5.

Berger, Peter. 1967. The Sacred Canopy. New York: Doubleday.

Berkman, Lisa F. and S. Leonard Syme. 1979 "Social networks, host resistance, and mortality: A nine-year follow-up study of Alameda county residents." American Journal of Epidemiology. 209 (1):204 (Set 2).

Brodsky, Betty. Spring 1988. Mental Health Attitudes and Practices of Soviet Jewish Immigrants. Health and Social Work. 130-136.

Byrne, Jean T. Jan./Feb. 1979. In Sickness and in Health: The Effects of Religion. Health Education. 6-10.

Campbell, Angus, Phillip E. Converse, and Willard L. Rogers. 1976. The Quality of American Life. New York: Russell Sage Foundation. 
Chamberlain, Kerry and Sheryl zika. 1988. Religiosity, Life Meaning and Wellbeing: Some Relationships in a Sample of Women. Journal for the Scientific Study of Religion, 27 (3), 411-420.

"Christians." November 3, 1989. Christianity Today. 52-57.

Cockerham, William C. 1986. Medical Sociology. Englewood cliffs, New Jersey: Prentice-Hall.

Coddington, R. 1972. The significance of life events as etiological factors in the disease of children-II. A study of a normal population. Journal Psychosomatic Research. 16, 205.

Cohen, Steven. 1989. American Assimilation or Jewish Revival? Bloomington: Indiana University Press.

Colfer, A. Michael. 1985. Morality, Kindred and Ethnic Boundary: A Study of the oregon old Believers. New York: AMS Press.

Cornwall, Marie. 1989. The Determinants of Religious Behavior: A Theoretical Model and Empirical Test. Social Forces. 68 (2): 572-592.

Croog, sydney $H$. and Levine, Sol. 1972. Religious Identity and Response to serious Illness: A Report on Heart Patients. Social Science \& Medicine. Vol. 6, 17-32.

Davidson, James D. Glock's Model of Religious Commitment: Assessing Some Different Approaches and Results. Review of Religious Research. Vol 16: No. 2, (Winter) 83-92.

Davidson, James D. 1969. Religious Belief As An Independent Variable. Journal for the Scientific study of Religion. 65-75.

Dinnerstein, Leonard and Reimers, David. 1988. Ethnic Americans: A History of Immigration. New York: Harper \& Row, Publishers. 221.

Douglas, Mary. 1977. Rules and Meanings: The Anthropology of Everday Knowledge. New York: Penguin Books.

Dulken, Diane. November 15, 1989. Soviet family whole again after 16 years. The oregonian D12.

Durkheim, Emile. 1961 [1912]. The Elementary Forms of Religious Life. Translated by J.W. Swain. New York: Collier. 
Eubank, N. 1974. The Russians in America. Minneapolis: Lerner Publications Company.

Farley, John E. 1988. Majority-Minority Relations. New Jersey: Prentice Hall, 205-209.

Ferraro, Kenneth F., and Cynthia M. Albrecht-Jensen. 1991. Does Religion Influence Adult Health? Journal for Scientific study of Religion, 30 (2), 193-202.

Field, Mark G. 1967. Soviet Socialized Medicine: An introduction. New York: The Free Press.

Geertsen, Reed., Klauber, Melville R., Rindflesh, Mark., Gray, Robert., Kane, Robert L. 1975. A Re-Examination of Suchman's Views on Social Factors in Health care Utilization. Journal of Health and Social Behavior Vol. $16,2,226-237$.

Gerber, stanford N. 1985. Russkoya Celo: The Ethnography of a Russigan-American Community. New York: AMS Press, 122 .

Glik, D. 1988. Symbolic, Ritual and Social Dynamics of Spiritual Healing. Social Science Medicine. Vol. 27, No. 11, 1197-1206.

Glik, D. 1990. Participation in spiritual Healing, Religiosity, and Mental Health. Sociological Inquiry. Vol. 60 , No. 2, 158-176.

Glik, D. 1986. Psychosocial Wellness Among Spiritual Healing Adherents. Social Science Medicine, 22, 579-586.

Glock, Charles Y. and Stark, Rodney. 1965. Religion and Society in Tension. Chicago: Rand McNally \& Company.

Goff, James R. 2/19/90. The Faith That claims. Christianity Today, 18-21.

Gottlieb, Annie. March 1990. Coming to America. McCall's, 70-79.

Gove, W.R. 1973. Sex, marital status and mortality. American Journal of Sociology. 45-67.

Hamilton, Don. June 16, 1988. Family's arrival spurs optimism. The oregonian E4.

Hannay, D.R. 1990. Religion and Health. Social Science Medicine. Vol. 14A, 1980, pp.683-685. 
Hollander, Paul. 1969. American and Soviet Society: A Reader in Comparative Sociology and Perception. New Jersey: Prentice-Hall 589.

Hollenweger, W. J. 1972. The Pentecostals. London.

Horowitz, Tamar. 1989. The Soviet Man in an Open Society. New York, London: University Press of America.

Hull, D. 1979. Migration, adaptation and illness: a review. Social. Science. Medicine. 13A, 25.

Idler, Ellen. 1979. Definitions of Health and Illness and Medical Sociology. Social Science \& Medicine. Vol. 13A, 723-731.

Idler, Ellen. September 1987. Religious Involvement and the Health of the Elderly: Some Hypotheses and an Initial Test. Social Forces Vol. 66:, 1227-239.

Jarvis, George and Northcott, Herbert C. 1987. Religion and Differences in Morbidity and Mortality. Social Science and Medicine Vol. 25, No. 7, 813-824.

Johnson, Malcolm L. 1975. Medical Sociology and Sociological Theory. Social Science and Medicine, vol. $9,227-232$.

Kass, Jaren D., Friedman, Richard., Leserman, Jane., Zuttermeister, Patricia C., Benson, Herbert. 1991. Health outcomes and a New Index of Spiritual Experience. Journal for the scientific study of Religion, 30 (2), 203-211.

Katz, A. 1971. The social causes of disease. In Recent Sociology. No. 3 New York: Macmillan.

Kessner, Thomas and Caroli, Betty Boyd. 1981. It's Good for the Important Things: To Leave Russia as a Jew. Today's Immigrants and Their stories. New York: Oxford University Press, 160-184.

Klein, Norman. 1979. Culture, Curers, and Contagion. Novato, California: Chandler \& Sharp Publishers, Inc.

Koenig, Harold George, Mona Smiley, and Joann Ploch Gonzales. 1988. Religion, health, and aging:A review and theoretical integration. Westport, CT: Greenwood Press.

Kolarz, walter. 1962. Religion in the soviet Union. London: Macmillan \& Co. Ltd. 
Landy, David. 1977. Culture, Disease, and Healing. New York: Macmillian Publishing Co., Inc.

Lane, Christel. 1978. Christian Religion in the soviet Union. Albany: State University of New York Press.

Lenski, Gerhard. 1961. The Religious Factor. Garden City, New York: Doubleday \& Company, Inc.

Leven, Jeffrey S. Harold Y. Vanderpool. 1987. Is Frequent Religious Attendance Really Conducive to Better Health?: Toward an Epidemiology of Religion. Social Science Medicine Vol. 24, No. 7, 589-600.

Levin, Jeffrey S. M.P.H., Markides, Kyriakos S, Ph.D. 1986. Religious Attendance and Subjective Health. Journal for the Scientific study of Religion, 25 (1), 1-139.

Life Application Bible. 1991. New International Version. Wheaton, Illinois: Tyndale House Publishers.

Lipson, Juliene G., Reizian, Alice E. and Meleis, Afat. 1987. Arab-American Patients: A Medical Record Review. Social Science and Medicine, Vol. 24 No. 2, 101-107.

Magnusson, Gudjon, and Goran Aurelius. 1980. Illness Behavior and Nationality: A study of Hospital Care Utilization by Immigrantss and Natives in a Stockholm District. Social Science and Medicine, Vol. 14A, 357362 .

McGuire, Meredith B. Winter, 1975. Toward a Sociological Interpretation of the "Catholic Pentecostal" Movement. Review of Religious Research, Vol. 16 No. 2, 94-104.

McGuire, Meredith B. 1982. Pentecostal Catholics. Philadelphia: Temple University Press

McGuire, Meredith B. 1988. Ritual Healing in Suburban America. New Brunswick and London: Rutgers University Press.

McGuire, Meredith B. 1990. Religion and the Body: Rematerializing the Human Body in the Social Sciences of Religion. Journal for the Scientific study of Religion, 29 (3), 283-296.

Medalie, J.H., Kahn H. A. and Neufield H.N. 1973. Fiveyear myocardial infarction incidence. II. Association of single variables to age and birth place. Journal of Chronic Diseases. 26, 324-349,. 
Meehan, Brian T. March 29, 1990. Glasnost comes to Holladay Park. The Oregonian A6, A 9 \& 10.

Miller, Jung Kim. October 1990. Use of Traditional Korean Health Care by Korean Immigrants to the United states. SSR. Vol. 75, No. 1, 38-43.

Moore, Laurie J. and James K. Boehnlein. 1992. Treating Psychiatric Disorders Among Mien Refugees From Highland Laos. Social Science Medicine. Vol. 32, No. 9. 1029-1036.

Moss, Gordon E. 1967. Illness, Immunity, and Social Interaction. New York: John Wiley.

Parrillo, Vincent N. 1985. Strangers to These Shores. New York: Macmillan Publishing Company.

Read, M. 1966. Culture, Health and Disease. Philadelphia and Montreal, Tavistock Publ.

Roberts, Keith. 1984. Religion in Sociological Perspective. Homewood, Illinois: Dorsey Press.

Roof, Wade Clark. 1975. On Conceptualizing Salience in Religious Commitment. Journal for the scientific study of Religion, 14, 11-128.

Rubenstein, sura. August 9, 1988. Jubilant refusenik heads for Portland. The oregonian B1, B12.

Rubenstein, Sura and Foster Church. June 3, 1988. Portlander's brother granted permission to leave Russia. The Oregonian A13.

Schiller, Preston L. and Jeffrey S. Leven. 1988. Is There a Religious Factor in Health care Utilization?: A Review." Social Science Medicine Vol. 27, No. 12, pp.1369-1379.

Schrader, Esther. December, 1989. Undertow. The New Republic. 11-12.

Schultz, Daniel S., MD, and Michael P. Rafferty, MD. February 1990. Soviet Health Care and Perestroika. American Journal of Public Health. Vol. 80, No. 2, p. 193-197.

Scotch, Norman A. PhD. August 1963. Sociocultural Factors in the Epidemiology of $\mathrm{Zulu}$ Hypertension. American Journal of Public Health, Vol. 53, No. 8, 1205-1212. 
Shiloh, Ailon and Selavan; Ida Cohen, Eds. 1973. Ethnic Groups of America: Their Morbidity, Mortality and Behavior Disorders. Springfield, Illinois: Charles C. Thomas, Publisher 331 .

Shipler, David K. 1989. Russia: Broken Idols, Solemn Dreams. New York: Penguin Books, 443.

Smolowe, Jill. January 29, 1990. The Killing Zone. Time, 30-32.

Spendal, Ron-Coordinator and Shari Cook, Fiscal officer. January 1990. The Challenge of Refugee Sponsorship: Soviet Evangelical Christian The oregon State Refugee Program, FFY 1989, Annual Report.

Stark, Rodney and Glock, Charles Y. 1968. American Piety: The Nature of Religious Commitment. Berkeley: University of California Press.

Suchman, Edward. 1964. Sociomedical variations among ethnic groups. American Journal of Sociology. 70 (November): $319-331$.

Sudman, Seymour, Monroe G. Sirken, and Charles D. Cowan. May 20, 1988. Sampling Rare and Elusive Populations. Science, Vol. 240, 991-996.

Thomas, L. Eugene and Pamela E. Cooper. 1978. Measurement and Incidence of Mystical Experiences: An Exploratory Study. Journal for the Scientific Study of Religion, 17 (4), 433-437.

Trier, Kathy K. and Anson Shupe. June 1991. prayer, Religiosity, and Healing in the Heartland, USA: A Research Note. Review of Religious Research, Vol. 32, No. $4,351-357$.

Troyer, Henry. 1988. Review of Cancer Among 4 Religious Sects: Evidence that Life-styles are Distinctive sets of Risk Factors. Social Science Medicine, Vol.26, No. 10, 1007-1017.

Wacker, Grant. 1986. Caring and curing. New York: MacMillan Pub. Co., 41-63.

Walker, Richard L. November 3, 1989. New U.S. Policy May Stem Flow of Soviet Christians. Christianity Today, 5257 . 
Walsh, Anthony. 1980. The Prophylactic Effect of Religion on Blood Pressure Levels Among a Sample of Immigrants. Social Science Medicine, Vol. 148, 59-63.

Washington (JTA). November 3-16 1990. 40,000 Soviet Jews to Come to the U.S. The Jewish Review, /Cheshvan 5751, 2 .

Williams, David, David B. Larson, Robert E. Buckler, Richard C. Heckmann, and Caroline M. Pyle. 1991. Religion and Psychological distress in a Community Sample. Social Science Medicine. Vol 32 , No. 11 , pp. 1257-1262.

World Relief. 1989. The Challenge of Refugee Sponsorship: Soviet Evangelical Christian Ethnic Profile.

Ximena Urrutia-Rojas, B.S.N., R.N., M.P.H., and Aday, Lu Ann, Ph.D. March 1991. A Framework for Community Assessment: Designing and Conducting a survey in a Hispanic Immigrant and Refugee Community. Public Health Nursing, Vol. 8 No. 1, 20-26. 
APPENDIX

RECORD OF INTERVIEWS

1. Pre-med student/interpreter $(6 / 91)$

2. Caseworker/ social service agency (1/92)

3. Recent refugees-interpreter/housewife $(12 / 91)$

4. Caseworker/ social service agency, refugee (4/92)

5. Health care worker-International Health clinic, refugee $(3 / 92)$

6. Educator-Lewis and Clark College, visiting professor $(2 / 92)$

7. Advocate/sponsor-Soviet refugees (10/91)

8. Caseworker/social service agency, refugee (1/92)

9. Caseworker/social service agency, refugee (1/92)

10. Minister $(11 / 91)$

11. Student $(12 / 92)$

12. Janitor - Refugee (1/92)

13. Educator/tutor (3/92)

14. Visiting Interpreter $(12 / 91)$

15. State Refugee Coordinator (11/90)

16. Various educators, health care workers, refugees; over a nine month period (6/91-4/92).

17. Case Manager, Center for Refugees (6/92)

18. Interpreter, children from Kiev (1/92)

19. Female Soviet student (11/91)

20. Female Sponsor, Soviet Refugee Family (3/92)

21. Male, young refugee, worker (1/91) 
22. Male, young refugee, worker (1/91)

23. Ukrainian visiting student (12/91)

24. Ukrainian mother and sponsor (1/92)

25. Assistant pastor (10/92) 


\section{ADDENDUM}

The way in which Glock and stark operationalized the belief dimension will serve to illustrate. A person who is rated high in religiosity indicates most of the following:

1. Certainty of the existence of God.

2. Belief in the divinity of Jesus.

3. Belief that Jesus was born of a virgin, actually walked on water, and will someday return.

4. Belief in miracles as reported in the Bible.

5. Belief in life after death.

6. Belief in the actual existence of the devil.

7. Belief that "a child is born into the world already guilty of sin" (Glock and stark 1968:22-44). 